\title{
DEVELOPING A DIGITAL GAME WITH HIGH-ABILITY/GIFTED STUDENTS IN A LOW-INCOME PUBLIC SCHOOL: A BRAZILIAN EXPERIENCE
}

\author{
Paula Mastroberti \\ Federal University of Rio Grande do Sul, Brazil
}

\begin{abstract}
This paper is about a digital game educational project developed with a group of high-ability/gifted students of the Room-Pole for Inclusion and Resources - High-ability and Giftedness (RPIR-HA/G). This Pole is located in a low-income district in Porto Alegre, Brazil. The project was one of the actions performed by the Extension Program Ludopoetics, which is, in turn, under the Sequential Graphic Arts on Media Culture for Children and Young: Education, Production, and Reading Research. I coordinate both as a teacher at the Visual Arts Department of Federal University of Rio Grande do Sul. The project was developed in 2019 and counted with a team composed of three undergraduate students. The Coordinator of the Pole, Aline Russo, has also supported this project; The Room-Pole IR-HA/G shelters about 25 students, most of them teenagers from 11 to 17 years old, coming from eighteen municipal public schools of the district. The project team planned and ministered a series of workshops about game creation from the basics: conception and design, art, animation, and computer programming. We applied a ludic methodology in order to engage the participants, and only open-source apps were used during the activities. Finally, the group of high-ability/gifted (HA/G) students were divided into two teams and developed two game projects. Our main objectives were to approach games as a serious subject of education and art education; to develop methodologies in art education using games as a strategy and as a result at the same time; and finally, to teach the high-ability/gifted students what is a game, how to do it and what are the required skills to make it. To support our proposals, we took Johann Huizinga, Ian Bogost, Scott Rogers, among other authors.
\end{abstract}

\section{KEYWORDS}

Game and Art Education, Game Creation, Game and Poetics, High-Ability and Gifted Students' Education

\section{LEVEL ONE: CONTEXTS}

I start this paper mentioning a Research Project, which I coordinate, titled Sequential Graphic Arts on Media Culture for Children and Young: Education, Production, and Reading. It began in 2017, and its ending date is scheduled to 2021. As the title says, the main objective is to investigate how children and young students from different schools (private and public, high and low income) learn visual aesthetics values through media culture. From that, we investigate what we can do, as trainers of Visual Art undergraduate students and future teachers, to approach their culture and to promote a more critical thinking and an aesthetic consciousness about it. In 2019, we decided to take games (digital, board, card, or mixed) as the central cultural phenomenon of investigation. Our surveys indicated that games, especially digital ones, are the most popular entertainment among the researched children and teenagers: about $80 \%$ of them would rather play with smartphones or consoles than read comics or books. As entertainment, playing games usually comes first even if compared to watching animation movies or live-action series, especially for boys. The social-economic factor does not seem to interfere with their preferences: the responses were quite similar. To low-income ones, a smartphone is an essential tool for everything: working, studying, communicating and having fun. The only difference between low-income and high-income groups was that the latter had better gadgets and better Internet access; high-income students also had to balance their leisure time with other activities in obedience to their parents. Kids of all social-economic levels mention their toy tablets. 
The surveys were applied on two public and two private schools at Porto Alegre. We used a qualitative methodology. The research was made in order to verify media culture habits and preferences of those students in which the sponsored undergraduate students were going to apply their work plans, in order to link visual arts teaching and media culture. To support our actions, we studied names such as Fernando Hernandez (2000) and Richard Shusterman (1998). I also created the Extension Program Ludopoetics to enlarge our possibilities of acting inside de game's field, and to deepen the studies about games, especially digital ones. I called it "ludopoetics" because my primary interest was to link playfulness to poetics. In other words, alongside with other philosophers' authors such as Huizinga (2010), I understand the game as an art and as a possibility to enlarge human aesthetics and ethical experience through the game's fictional interactive environments.

I worked with three undergraduate students and, on 2019, we were invited by Aline Russo, coordinator of the Room-Pole to Inclusion and Resources - High-Ability and Giftedness (RPIR - HA/G), to act with a group of high-ability ${ }^{1}$. We organized and offered them a workshop plan composed of seven parts on how to develop a digital game, which was enthusiastically approved. The project was ministered to 11 high-ability/gifted students whose ages varied between 13 and 16 years-old, boys and girls, all of them belonging to unstructured low-income families, with problems of self-esteem, depression, and others.

What follows next is a description of the operations in the Room-Pole IR - HA/G. Section 2 is based on the reports of the undergratuated students, Aline Russo, and Aline Letícia Machado's undergraduate thesis. I am very grateful for the commitment of this team and the Coordinator of the Room-Pole, who welcomed us. This paper would not be possible without their accurate descriptions and the pictures and videos they carefully took. I would also like to extend my gratitude to all HA/G boys and girls that engaged so enthusiastically in our proposals. After reporting this experience, I will make some final considerations.

\section{LEVEL TWO: THE WORKSHOPS}

\subsection{The Plan}

The team of monitors was composed of three undergraduate students: Emmanuel Rambo dos Santos, Iris Matiele Ozuna, and Aline Letícia Machado. Their planning involved seven steps (or stages), applied as if they were levels of a game structure. The participants could not pass to the next level without accomplishing the previous one. The steps were as follows:

Step 1 - Presentation of the project and the undergraduate's team; presentation of the HA/G students; interviews;

Step 2 - Introduction workshop: what is a game, how to make a game, relationship between game and art; organization of development teams;

Step 3 - Workshop about how to plan a game: argument and game design;

Step 4 - Digital art and graphic design workshop: characters concepts, scenarios, and animation using the open-sources apps Krita and Autodesk Sketchbook;

Step 5 - Programming workshop using the open-source game creator GDevelop;

Step 6 - Excursion to University of Vale do Rio dos Sinos (UNISINOS), to visit the Digital Game Course and to meet the team of the Atomic Rocket Entertainment Project supervised by Rossana Baptista Queiroz;

Step 7 - Completion of the projects and collective evaluation.

We planned weekly workshops, always on Thursday, from $9 \mathrm{~h}$ to $12 \mathrm{~h} \mathrm{AM}$, as they should occur on the inverse turn of their school classes, inside the Room-Pole. We did not force all the HA/G students to engage and 11 participants enrolled, being three girls and eight boys. Their ages ranged from 11 to 16 years old. Many other students wanted to participate, but they could not, because their schedules did not match to the workshops'. We based the methodology plan on Scott Rogers's roles and production categories (Rogers, 2014).

\footnotetext{
${ }^{1}$ A person is considered with high-ability or giftedness when he or she presents a high-level skill. Sometimes the HA/G person gets very involved with a task, seeking to deepen his or her abilities and gifts. He or she can also be very creative, using his or her knowledge to innovate in his or her area of interest (Renzulli \& Reis, 2004). The RPIR - HA/G is a city hall organ and operates from inside a municipal school. It serves eighteen municipal schools in Porto Alegre, all of them located in low-income districts. Aline Russo coordinates this Room-Pole since 2014 .
} 


\subsection{Acting}

\subsubsection{Interviewing}

Before starting the workshops, the team held a meeting to introduce themselves and to explain the project to the group of high-ability students. They also interviewed them in order to know their opinions and preferences about games. We used Google Form to register their answers. Under the question "What are you used to hear about digital games from your parents?", they answered that their parents used to say that games might provoke addiction, or they were just a silly hobby, not useful at all. Under the question "Do you think digital games can cause you any harm?" many of them were in doubt, and about one third answered "yes" mentioning "addiction" as the first harm, and then "vision problems" or "tendonitis." Nevertheless, at the same time, they also pointed out that games are an entertaining way to learn other languages or to develop reasoning. It is important to notice that not even one of them quoted games as a possibility to experience fiction narratives or to interact with different environments, even virtual (they may hardly have access to augmented reality). A game as Pokémon Go, for example, demands powerful devices, and a broad internet band. The next question was: "Do you think games can be a work of art?" The answers were very diverse. They highlighted the visual graphics as a fundamental characteristic to influence expression and emotional feelings. The visual aspects of a game are also valued as a condition to recognize a game as a good one. According to them, the visual arts movements and animation are essential to guarantee a more emotional immersion. Most of them prefer Role Playing Games (RPG), but they declare to appreciate shooting, strategies, or construction games too. Against our expectations, the HA/G youngsters did not mention any puzzles or logic games. They quoted League of Legends, Paladins, Grand Theft Auto (GTA), Minecraft, Roblox, The Sims, Fortnite among their favorites. Cell phones and computers tied as the most used devices. The console came in second place.

It is imperative to mention that the absolute majority had never thought of creating a game of their own. So, one of the reasons they agreed to engage in our project could be that they were very curious about what was going to happen.

\subsubsection{What is a Game? How to Create it?}

In the first workshop, the monitors presented the steps of making a game, emphasizing its more essential aspects. The students should pay attention to rule planning, concept arts, game design, character animation, soundtrack, and programming. Then, they asked the participants to divide in two groups, choosing what kind of function each one would like to perform the most, according to Rogers' categories: artist or animator, level or game designer, programmer, sound maker, tester, or leader-writer. The monitors worked on making them bring up their primary skills and subjects of interest; then, they helped the students fit them in Roger's categories as best as possible or according to their preferences. The girls' abilities leaned toward arts (drawing and painting) and one of them proved to be a perfect leader. The boys were more inclined to creative writing (poetry, stories), programming, animation, leadership, and digital design. The girls preferred to stay together. As they were eleven in total, two of the boys took the initiative and went to the girls' team. This way, there were three girls and two boys on one team, and six boys on the other. From now on, I will name the girls-and-boys team, Team A, and the o-boys team, Team B. The next propositions included a quick layout to what kind of game both groups would like to create and sketches of a protagonist character.

\subsubsection{Practice 1: Plot, Rules, and Game Design}

In the second workshop, the monitors were happy when they realized that both teams brought many ideas to work on their games. The students seemed very excited and looked forward to the beginning. So, the undergraduates just supervised the tasks and roles that each team member was going to perform. They also helped them organizing the main game concepts. In this workshop, the teams took the time to define main game characteristics: the story, the basic rules, and the general visual concepts. They also developed and presented a game's map, drawing it on the blackboard. 


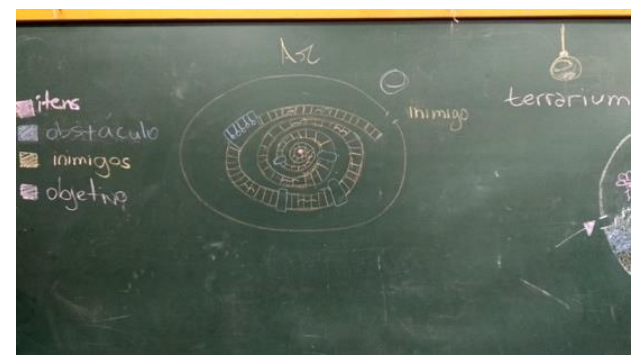

( a )

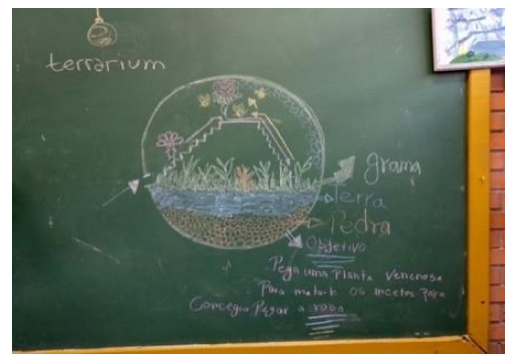

( b )

Figure $1(\mathrm{a}, \mathrm{b})$. The game map of Team A. Program's archive

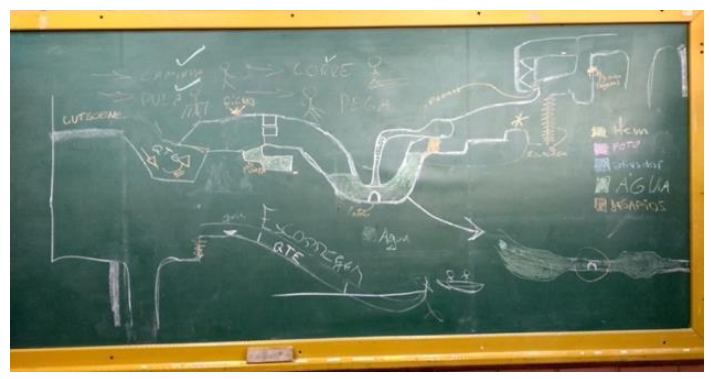

Figure 2. A game map of Team B. Program's archive

\subsubsection{Practice 2: Games' Development (Script, Characters' Design, and Level Design)}

In this stage, the Team A stood out. They seemed better organized, and they executed the tasks more efficiently. Consequently, the monitors gave more support to Team B and just observed the other one. In his report, Emmanuel wrote that both sides are very talented and had excellent ideas for their projects. Team B, in particular, looked very nervous and took a little more time to start it, maybe because they were very self-critical. Nevertheless, Iris Ozuna reported us problems: some of the boys had have difficulties to be present at the workshops, due to family problems or adverse economic situation (for example, one of them at times had not even had a coat to wear). Communication by cellphone was also trickier.

The Team A plot was about an astronaut who needed to save the Earth searching for resources in his peregrination through the universe while many alien enemies challenged him. The Team B plot was about a ghost (a guy who died in an accident) who should overcome his fears, level by level until he reached the eternal peace. Their choices reinforced the qualities we desired to emulate in our workshop project: a poetic charge reflected on consistent playful stories, building with aesthetical and ethical values.

\subsubsection{Practice 3: Games' Development (Art Design and Edition, Sound Design)}

For this workshop, we got some tablets from the LIFE (Interdisciplinary Laboratory to Educational Training), a Program of our university for educational needs. The artists on each team learned how to work on free apps like Autodesk Sketchbook to draw and paint characters, elements, and sceneries, and the Krita app to animate them. However, due to technical reasons and the few numbers of devices, Iris Ozuna used analogic techniques to make them understand how animation frames work, such as drawing over tracing paper or paper cutouts to produce stop motion. To those of them who were not interested in developing artistic abilities, the monitors taught how to create sound effects by using cellphones in order to register musical instruments and school noises around. I must point out that all participants, after finishing their specific tasks, used to help those who did not finish theirs yet. This pro-activity generated an atmosphere of unprecedented cooperation among them, as they had never produced anything together, even though they had met before in other meetings in the Room-Pole. 


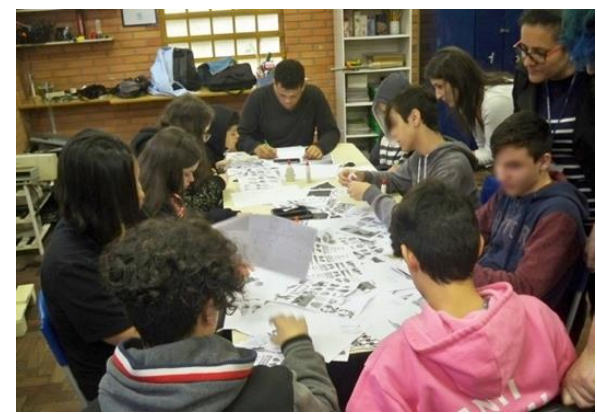

Figure 3. The HA/G students work on collages. This exercise aimed to deconstruct the characters' bodies in order to stimulate non-conventional forms. Aline Letícia Machado, in white cloth, supervises a student on the right. Aline Russo, using glasses, appears in front of her. Program's archive

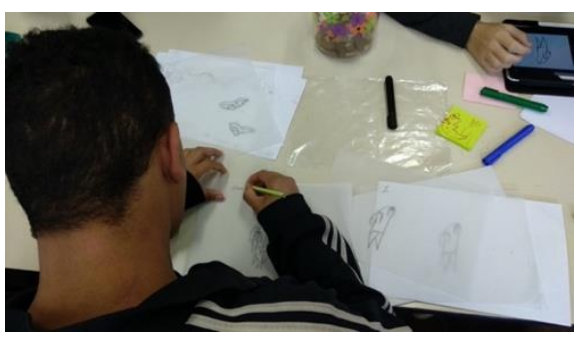

Figure 4. The students practiced analogic and digital technics to develop arts and animation. Below, while a student draws over vegetal papers, his fellow is animating using a tablet. They digitalized all analogic rafts later. Program's archive

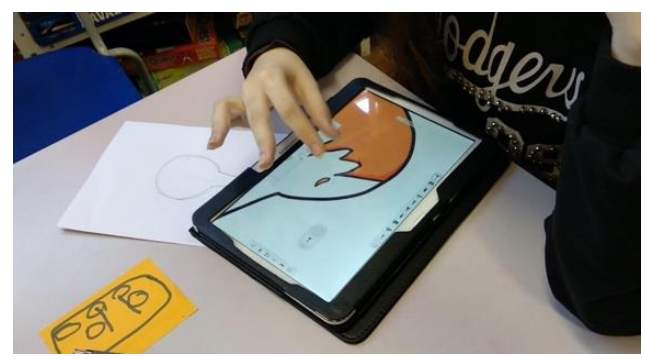

Figure 5. A girl draws a scenario element using a tablet. Unfortunately, many of the artwork could not be used in the final prototype, because they did not have enough time to finish the animation in order to use them. Program's archive

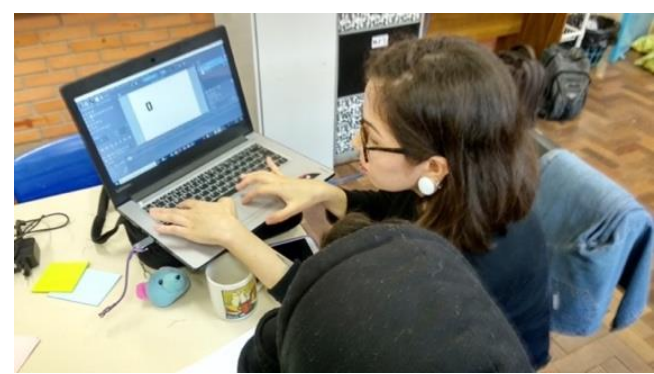

Figure 6. Iris Ozuna is teaching a boy how to animate using Krita's tools. Program's archive 


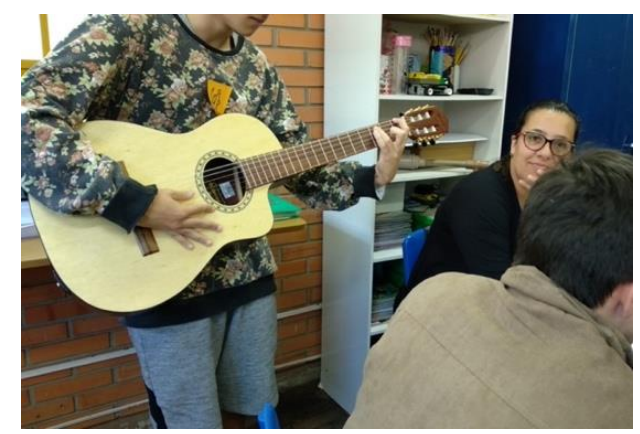

Figure 7. A student with musical skills is trying to create sound effects playing his guitar. Program's archive

\subsubsection{Practice 4: Game's Development (Programming)}

The monitors introduced an open-source cross-platform app called G-Develop. They installed it on Aline Russo's notebook, and the students could learn some basic notions. None of the monitors were experts in programming, so we called a teacher from the Digital Games Course of the University of Vale do Rio dos Sinos, João Ricardo de Bittencourt Menezes, to train them first. We chose G-Develop not just because it is an open-source and free platform, but because it is easy to manipulate, and people of all ages can learn how to operate it. A thirteen-year-old boy was delighted. He had never tried programming before, but he got so fond of it that he exclaimed to have finally discovered what he wanted to do for a living.

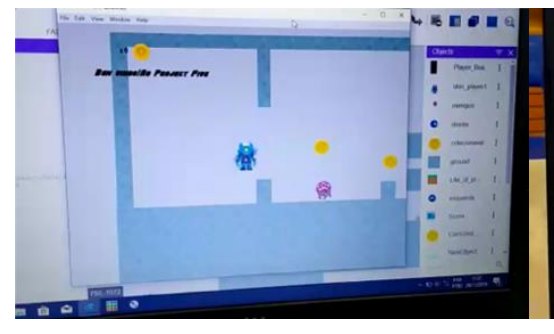

( a )

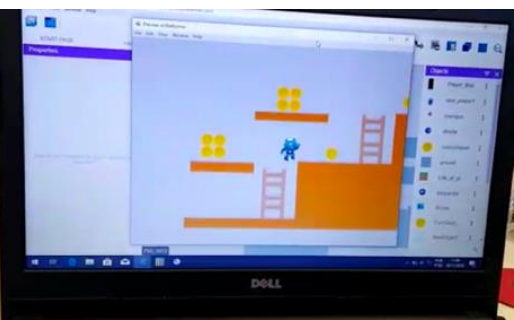

( b )

Figure 8 (a, b). Video frames of the game's build programmed by the thirteen-year-old boy. Program's archive

\subsubsection{Final Meeting: Presentation and Collective Evaluation of the Teams' Projects}

Both sides had to present their game projects. They should explain what the game goals were, and what would be necessary to conclude them. Team A finished their prototype with a complete phase, but they have to put aside the girl's arts and substitute them by templates. Team B did not finish theirs, partly because their design was more complicated, partly because of the problems already mentioned in Section 2.2.4. After it, monitors, students, and the coordinator discussed and reflected on the experience. They commented on their main difficulties and the positive learning they had. The students claimed for more workshops to conclude their games. The monitors complimented both teams' goals and their collectiveness spirit, they also highlighted that the most crucial workshops were to introduce the required steps to develop a game, to stimulate some skills and the collaborative spirit necessary to do that.

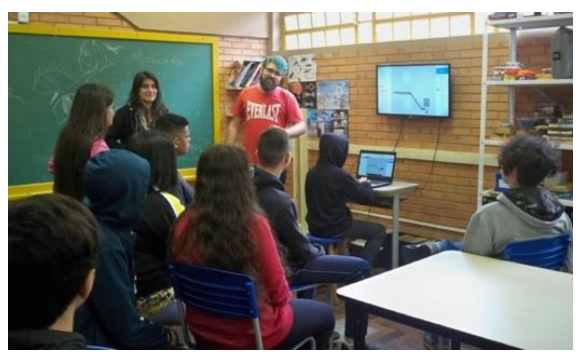

Figure 9. The Team A's presentation. We can see Aline Leticia and Emmanuel at the center, behind the participants. Program's archive 


\subsection{Planned and Non-Planned Activities: Outspreads}

We intended to do the excursion to UNISINOS before the final meeting, but the group only visited the University almost a week later. Aline Russo, the Room-Pole Coordinator, went along with them. This visiting was essential for many reasons: first, they did not know that a degree course to train professional game developers existed; second, they had never been to any university campus before. We chose this university because ours does not have a similar degree course. Besides, UNISINOS is a partner in Ludopoetic Program. They visited the Atomic Rocket Entertainment Project Laboratory, and they talked to the undergraduate students and their coordinator, Rossana Baptista Queiroz. The students could test some games that were being developed by the Atomic team.

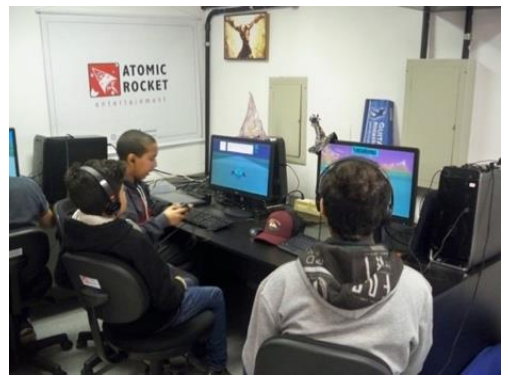

( a )

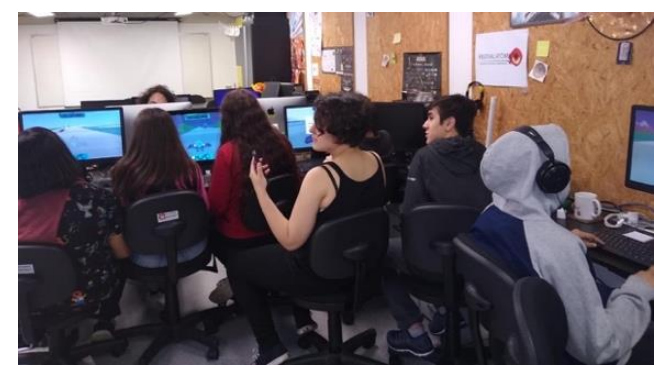

( b )

Figure 10 (a, b). The visit to Atomic Rocket Entertainment Project. Program archive

After that, the monitors and Aline prepared a farewell party for everybody. Emmanuel, Iris, and Aline Leticia commented later on how they loved the experience and how they still miss the students very much. The participants proposed to continue the meetings to finish their games, once they did not have enough time, and so Emmanuel and Iris continued to go there for a while to assist their work. Both presented the results of this project twice in 2019: first, at the Extension Hall of our university, and another to the Visual Arts Education Degree Course freshman. At that time, Aline Leticia was busy producing her undergraduate thesis, which is about this project (Machado, 2019), and could not go back to Room-Pole anymore. She graduated in 2019. Aline Russo related that the students got so involved with this project that they took every time they could to continue working on their games, even after the project's closure. By messenger, she particularly mentioned that thirteen-year-old boy who decided to be a programmer, she said he went beyond what he was taught, reaching the third level in high-ability/giftedness, according to Joseph S. Renzulli and Sally M. Reis (2004). He got completely obsessed with deepening his skills and started to create a new game totally by himself.

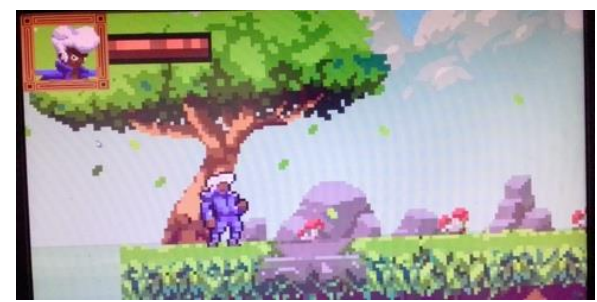

Figure 11. Image of the boy's new game sent later through Whatsapp by Aline Russo. Program archive

In her report, she also praised the monitors' performance. In essence, they knew how to teach without taking away the autonomy of the participants, and they were supporting, purposeful, and active as teachers, keeping the students engaged. But, what about the HA/G students? What they had to say about the experience? We collected some testimonials by Whatsapp, which I translated from Portuguese:

"I think it was an outstanding experience and I hope it happens again. I found the learning to be very good, but $[\ldots]$ the experience could be more dynamic, because I was a little bored" (a 11-year-old boy); 
"I learned about game development, and to make them in groups showed us the importance of an internal organization, this was the major difficulty we faced during the project execution" (a 14-year-old boy);

"I [...] liked the teachers (Iris and Emmanuel) because they were funny, but when it was needed $[\ldots]$ they called out our attention. I didn't like that it was too short, it was so cool [...] I didn't miss anything, they taught us all we need to know. I liked practically everything, theory and practice classes, I liked the excursion, and I think nothing should be different." (another 11-year-old boy).

We understood the first 11-year-old boy comment as a warning to be more careful about our dynamics and actions, trying to give attention to each participant's rhythm and maturity.

Having reported on the workshop, I now turn to my own considerations.

\section{FINAL LEVEL: WINNERS}

The first lesson we can take from this report is that it is not easy to create a game. I am not just talking about financial resources, cutting-edge technologies, or high skills. I am talking about ethical qualities such as perseverance, patience, mutual respect and collaboration. To be a game developer requires the same competences as to be a game player: when one plays, it supposes one has agreed with the rules. The players must have mutual understanding, and the interaction with a fictional play's ambiance implies accepting whatever happens inside, or they will not emulate playfulness. Above all, playfulness must bring joy and pleasure feelings to every player, even when he or she loses. The playfulness sensation is what matters, Ian Bogost (2010) called it engagement. He says the engagement qualities of a game depend on the sophisticated rhetoric of its system, like visual and sound effects, level design, and others. However, I prefer to enlarge this conception, including the player forms of interaction (actions, choices, interpretations) and the emotions involved when he or she emulates a game ambiance.

As I considered in a highlighted paper published in 2019, in the Brazilian Game Society Symposium at Rio de Janeiro (Mastroberti, 2019), we need to amplify game's studies towards a more humanistic view, joining human themes to technological training. It implies to understand what the ludopoetics concept means: a ludic experience emulating a poetical ambiance, understanding poetics as a combination of aesthetic and ethical values, as according to Aristoteles (2016). We can apply ludopoetics ideas to all knowledge fields and professions. In order to be better artists or educators, we need to perform playfully. We need to potentialize our classes and schools, our studios, and poetic works to a ludic, defiant, and engaged experience, capable of raising our curiosity, our desire of knowledge. Likewise, if we want to make a game, we have to approach it as any creative and challenging humanistic work.

The HA/G students proved to be very enthusiastic about the idea of a game's creation. They did learn basic notions about it, such as how to make digital art, how to structure a level game design, how to animate, how to program, all of that using open-source technology. On the other side, the instructors also challenged them to develop qualities as cooperation, mutual agreement, patience, and resignation when it was necessary to abandon a path or to remake things that did not work out. Those were fundamental skills to develop, mainly because people frequently highlight their giftedness at the expense of their emotions. We cannot forget they are in a social-economic disadvantaged condition as well. They have to deal with the most adverse situations, and we need to strengthen them to overcome what may. So, during the process of making their games, the participants had to give up many things: some artworks ended up not being used, some more complex ideas were left out. Moreover, they got disappointed when they realized they would not complete their games on time. However, as the monitors and the Coordinator of the Room-Pole perceived and let them know, they achieved crucial goals, some of them not being planned.

The monitors and the students transformed the Room-Pole in a playful place to be. The high-ability students had never developed a project together and had to look after each other in order to learn problem resolution, deepening their relationships. The undergraduate monitors' age was an advantage and a problem at the same time. Due to the age factor they established an excellent communication with the school students, they had similar cultural preferences, and they built a friendly atmosphere. However, at times, the Coordinator had to interfere when they lost control. That happened not only because the monitors were young, but also because the experience of teaching was new for them. Their age and lack of experience defied them to balance 
camaraderie and educational attitude without losing spontaneous affectiveness. Finally, during the period they were together, they created and played a real game indeed, even without notice: an educational and poetic one. I am sure it was an unforgettable and playful experience for all sides, monitors, and students.

When the project ended, Aline Russo asked for more projects like this one. At this moment, I have a new sponsored student working at the Room-Pole developing an animation movie project. Another digital game project may happen there soon, as part of an interdisciplinary project of our university, under the coordination of the Physical Institute. So, the game is not over.

\section{REFERENCES}

Aristoteles, 2016. Poetica. 34, São Paulo, BR.

Bogost, I., 2010. Persuasive games: the expressive power of videogames. MIT Press, Massachusetts, USA.

Hernandez, F., 2000. Cultura visual, mudança educativa e projeto de trabalho. Penso, Porto Alegre, BR.

Huizinga, J., 2010. Homo ludens. Perspectiva, São Paulo, BR.

Machado, A. L., 2019. A arte e a educação em jogo: colaboratividade na produção de um jogo digital. Undergraduate thesis. Lume Digital Repository, UFRGS, BR. Link access: https://lume.ufrgs.br/handle/10183/206259

Mastroberti, P., 2019, Ludopoéticas: Relações possíveis entre jogo, arte e educação a partir de ações de pesquisa. Proceedings of SB Games - Education Track. Rio de Janeiro, Brazil, no page numbers. Link access: https://www.sbgames.org/sbgames2019/files/papers/EducacaoFull/195670.pdf.

Renzulli, J. S. and Reis, S. M., 2004. Identification of students for gifted and talented programs. Corwin, Thousand Oaks, CA.

Rogers S., 2014. Level up: the guide to great video game design. Wiley, Hoboken, USA.

Shusterman, R., 1998. Vivendo a arte: o pensamento pragmatista e a estética popular. 34, São Paulo, BR. 